Bajopas Vol. 1 No. 1 December 2008

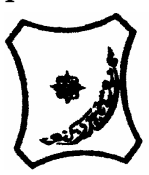

Bayero Journal of Pure and Applied Sciences, 1(1):88 - 94

Received: November, 2008

Accepted: December, 2008

\title{
EFFECT OF LEAD ON ZOOPLANKTON DYNAMICS IN CHALLAWA RIVER, KANO STATE, NIGERIA
}

\author{
*Ibrahim, S. and Abdullahi, B. A. \\ Department of Biological Sciences, Bayero University, Kano, P. M. B. 3011, Kano, Nigeria \\ *Correspondence Author
}

\begin{abstract}
Lead concentration was determined with the aid of Atomic Absorption Spectrophotometer while zooplankton were collected with the aid of plankton net and analysed microscopically to assess their diversity and density in the Challawa River at four selected sites on fortnight basis between July 2006 and December 2007. The mean lead concentration was between 125 mg/L and 2.84 $\mathrm{mg} / \mathrm{L}$, far above maximum acceptable and allowable concentrations in drinking water of $0.05 \mathrm{mg} / \mathrm{L}$ and $0.10 \mathrm{mg} / \mathrm{L}$ respectively (WHO, 1996). The mean zooplankton density ranged between 3.09 Org/L and 10.26 Org/L. Only five protozoan, two insect, four copepod (plus one naplius I), one cladoceran and five rotifer species were identified during the study. The river quality decreased down stream, with least plankton recovery of 4 species at the industrial effluent inflow site and highest off-stream (site A) with 14 species. The site that experiences a direct inflow of industrial effluent was the most polluted (Odum's Index $=0.22$ ). Significant differences occurred in the lead concentration between the sites $(P<0.01)$ and the seasons $(P<0.05)$. The lead concentration at the sampling sites was negatively correlated with zooplankton diversity $(r=-0.28734)$. It was feared that consumption of raw Challawa River water can over time lead to bioaccumulation of this heavy metal with possible negative consequences on health and wellbeing of man. Likewise, the low zooplankton diversity and density in this river could largely be attributed to its poor physicochemical status that had detrimental effect on them especially at the industrial effluent inflow site.
\end{abstract}

Key words: Challawa River, lead, zooplankton dynamics, pollution, Kano-Nigeria.

\section{INTRODUCTION}

Good quality water is of paramount importance not only to the well-being of man (WHO, 2003) but also other plants and animals in aquatic ecosystems of which planktons are inclusive. Thus, for consumption purposes, raw water from rivers is treated to portable condition in accordance with set standards (Kawo and Ajagbe, 2001; WHO, 1996). Deviation from the standards make affected population to be exposed to ailments of various types some of which can be fatal (WHO, 2003). According to Elliot (1996), sources of pollution in inland and coastal waters of Nigeria include agro-chemicals (herbicides, pesticides etc); industrial effluents (heavy metals etc); domestic sewage and refuse; crude oil spillage and toxic petrochemical by-products. Other sources of harmful chemicals include 'poisonous' plants and plant byproducts, which are often used to catch fishes. This subsequently, contributes to water pollution with a lot of negative effects on some important aquatic fauna and flora (Omoregie, et al., 1995; Akingide, 2000; Kawo and Deeni, 2002). The popular heavy metals include cadmium, chromium, cobalt, copper, lead, nickel and zinc. Results of several studies have shown that physical and chemical condition of aquatic ecosystems determine the occurrence, diversity and density of both flora and fauna in any given habitat, which may change with season of the year (Ayodele and Adeniyi, 2006; Okogwu and Ugwumba, 2006).
The studies conducted by Abubakar (1998) and Hadiza (1998) both on pollution level caused by industrial effluent on the plankton of Challawa River, showed a positive indication of pollution in the river. Furthermore, Aminu (1988) reported a case of contamination by heavy metals such as nickel, copper, cadmium and cobalt in effluents from Sharada Industrial Area of Kano metropolis and concluded that there was likelihood that these metallic pollutants could pollute Challawa River since the effluents are finally drained into it. Consequently, the present study was conducted with the view to assessing the lead level in the Challawa River being one of the most important heavy metals with a lot of health implications on both humans and other organisms (aquatic species inclusive) since the river serves as a source of potable water in Kano metropolis and to determine its effect on the population dynamics of zooplankton in the river at the designated sampling sites.

\section{MATERIALS AND METHODS}

The Study Sites: Challawa River

Challawa River is located within latitude $11^{\circ} 55^{\prime} \mathrm{N}$ and longitude $8^{\circ} 22$ 'E and ranked as second largest river in Kano after Kano River. The river made a confluence with Kano River at Tamburawa village, some $20 \mathrm{~km}$ from Kano closed settled zone. For decades, the river system sustains communities along its course, particularly agricultural activities. Kano State Challawa Waterworks is situated on the Challawa River. 
Bajopas Vol. 1 No. 1 December 2008

Thus, the river provides sources of water for agricultural, industrial and domestic purposes in Kano metropolis. In addition, one of the major industrial estates in Kano is located around the river system i.e. the Challawa Industrial Estate and depends largely on the waterworks for its water needs. Similarly, significant parts of the urban Kano population rely heavily on the water for their domestic activities although the new Tamburawa Waterworks, that was about to be commissioned at the time of this compilation was expected to go a long way in alleviating some of the water needs in the state. This waterworks was hoped to provide 150 million $\mathrm{M}^{3}$ of potable water daily (Africa, 2007).

Sampling Sites: Four (4) sampling sites designated as A, B, C and D were selected for the purpose of this study. GPS 12 model (GARMIN, USA) was used in marking the global positions of the sites. Site $A$ : This site is on the watercourse of the Challawa River ( $N$ $\left.11^{\circ} 52.689^{\prime}, \mathrm{E} 008^{\circ} 28.001^{\prime}\right)$ and extends some 120 meters west to the edge of the new bridge leading to Garu village. At this site, human activities such as fishing, washing, sand collection and other domestic activities occur regularly. Site $\mathrm{B}$ : This site is near the river intake point ( $\left.11^{\circ} 52.718^{\prime}, \mathrm{E} 008^{\circ} 28.183^{\prime}\right)$; the point at which the Kano State Waterworks draws its raw water to the treatment plant for purification purposes prior to its release to the public for various uses. Site C: This is the site (N 11 ${ }^{\circ} 52.745^{\prime}, \mathrm{E}$ $008^{\circ} 28.473$ ) where raw industrial effluent, primarily from food, textile and tannery industries was mixed up with the Challawa River water. Site D: This is at Tamburawa, near the bridge (N 11 ${ }^{\circ} 50.503^{\prime}$, E $008^{\circ} 30.979$ '); where Challawa River forms a confluence with Kano River along Kano-Zaria Road. At this site, agricultural activities, fishing and other activities are taking place. This site is near the new Tamburawa Water Treatment Plant.

Sample Collection: Water samples were collected on fortnight basis between 8:00 - 10:00 a.m. from July 2006 to December 2007 and analysed for its lead content and diversity, density and distribution of zooplankton in the samples.

Determination of Lead: Atomic Absorption spectrometric method was adopted.

\section{a) Sample Digestion Procedure:} Environmental Protection Agency (EPA) vigorous digestion method with slight modification (upward adjustment of samples and acid volumes to take care of low metal concentrations) as described by Gregg (1989) was adopted. The procedure involved transferring $100 \mathrm{~cm}^{3}$ of acidified water sample $(\mathrm{pH}=$ 2) from each of the sites into a Pyrex beaker with $10 \mathrm{~cm}^{3}$ conc. $\mathrm{HNO}_{3}$ (Supplied by Sallymore (Nig.) Limited). The sample was always boiled slowly and evaporated on a hot plate to the lowest possible volume (about $20 \mathrm{~cm}^{3}$ ) before precipitation occurred. The beaker was cooled and another $5 \mathrm{~cm}^{3}$ concentrated $\mathrm{HNO}_{3}$ added, returned to the hot plate and covered with a watch glass. The temperature of the hot plate was increased to obtain a gentle refluxing action. Heating was continued with addition of conc. $\mathrm{HNO}_{3}$ as necessary till digestion was complete (shown by formation of a light-coloured solution). The sample was evaporated to dryness (but not baked). The beaker was cooled and $5 \mathrm{~cm}^{3} 1: 1 \mathrm{HCl}$ (Supplied by Sallymore (Nig.) Limited) solution added, warmed again followed by the addition of $5 \mathrm{~cm}^{3}$ of $5 \mathrm{~N} \mathrm{NaOH}$ (Supplied by Sallymore (Nig.) Limited). The wall of the beaker and watch glass were washed with distilled deionised water and filtered. Blank was prepared in the same way as above (with $100 \mathrm{~cm}^{3}$ distilled deionised water) instead of the sample solution.

b) pH Adjustment and Atomic Absorption Spectrometry: The filtrate was transferred to $100 \mathrm{~cm}^{3}$ volumetric flask and diluted to mark with distilled deionised water. The $\mathrm{pH}$ of the resulting solution was adjusted to 4 by drop wise addition of $5 \mathrm{~N}$ $\mathrm{NaOH}$ solution. The above solution was analysed for the presence of lead using Atomic Absorption Spectrophotometer (AAS, Alpha 4 model, U.K.) by determining the absorbance of the element at $217 \mathrm{~nm}$ wave length (as described by the manufacturers, Chemtech Analytical, U.K.). Concentration of the element was obtained from standard calibration plot for absorbance against standard lead concentrations (Appendix I).

Zooplankton Sampling: The zooplanktons were sampled with the aid of plankton net (made of bolting cloth with a fine mesh aperture, 20-60 m, with a small bottle container of $30 \mathrm{~cm}^{3}$ capacity attached to its narrow end). The water sample collected at each site was always carefully emptied into a dark sample bottle of about $100 \mathrm{~cm}^{3}$ capacity and always rinsed with distilled water in-between samples to avoid contamination.

Centrifugation and Preservation of Zooplankton Samples: The collected samples were further centrifuged in the laboratory at $1500 \mathrm{rpm}$ using centrifuge machine (Centromix), Huddersfield, England). A portion of each of the samples above was examined fresh with the aid of a light microscope while the remaining was preserved with $4 \%$ formalin (Supplied by Sallymore (Nig.) Limited) for detailed microscopic analysis (Jeje and Fernando, 1986).

Identification and Counting of the Zooplanktons: The zooplankton samples collected from the river were observed and identified with the aid of light microscope (Olympus, Japan) and identification guides by Edmondson (1959), Pennak (1978), Jeje and Fernando (1986), Patterson and Hedley (1992) and Mission Creek (2004). Glycerine (Supplied by Sallymore (Nig.) Limited) and strong sugar solution were used as mountants for fastswimming organisms in order to slow down their movement and therefore make the identification and counting easier. 
Plankton abundance was estimated with the aid of a compound microscope (Olympus, Japan) as described by Nlewadim and Adeyemo (1998) using the following relationship: -

$$
A=\frac{Y Z}{a x} ; \text { Where, }
$$

$A=$ Average number of zooplankton per litre

$A=$ original volume of the water sample (litre)

$Y=$ average number of plankton per sample

$\mathrm{X}=$ volume of sample or counting chamber examined $(\mathrm{ml})$

$\mathrm{Z}=$ concentration volume $(\mathrm{ml})$

Odum's index was also computed as follows to determine the pollution status of the river at different sites. Thus, Odum's Index = Total number of species in a sample or site Total number of individuals of all the species

Statistical Analyses: With the aid of Microsoft Excel and SAS (1985) seasonal variation in the lead concentration and zooplankton density during the wet (May - October) and dry seasons (November - April), and between the sites were compared using Analysis of Variance (ANOVA) for significant differences or otherwise. Similarly, Pearson Correlation Analysis was carried out to measure the degree of linear relationship between the lead and the zooplanktons (Meyer, 1998; and Maiti, 2004). Also, Odum's Index was employed to assess the pollution status of the river based on the zooplankton data generated at the sampling sites.

\section{RESULTS}

The results of variations in lead concentration $(\mathrm{mg} / \mathrm{L})$ and total zooplankton density (Org/L) at the sampling sites are presented in Table 1and Figure 1 . The table shows that Site A and B had lower lead concentrations than the other two sites. The lead concentration at site A ranged from $0.74 \mathrm{mg} / \mathrm{L}$ (October 2006, January and October, 2007) to $2.04 \mathrm{mg} / \mathrm{L}$ (March, 2007). Similarly, zooplankton density at site A ranged from 0.000rg/L (December, 2007) to 35.91Org/L (August, 2007). The mean lead and zooplankton densities at this site were $1.25 \mathrm{mg} / \mathrm{L}$ and $10.260 \mathrm{rg} / \mathrm{L}$ respectively. Double maxima in zooplankton density occurred at site A in April (dry season) and August (wet season) in 2007. Table 1 also showed that lead concentration at site $B$ was on the average higher than that of site $C$ and $D$. At site $B$, the lead concentration varied from $0.93 \mathrm{mg} / \mathrm{L}$ (September 2007) in wet season to $2.41 \mathrm{mg} / \mathrm{L}$ also recorded in the wet season (July 2007) with corresponding zooplankton densities of $8.250 \mathrm{rg} / \mathrm{L}$ and $7.950 \mathrm{rg} / \mathrm{L}$ respectively. While zero (0.000rg/L) zooplankton recovery was made only in December 2007 at site A, August and October to December 2006, were with out zooplanktons at site B, which spread across the seasons. On the other hand, highest lead concentrations were recorded at site $C$ and least zooplankton densities with several months having complete absence of the zooplanktons. The mean lead concentration and zooplankton density at site $C$ were $2.84 \mathrm{mg} / \mathrm{L}$ and $3.09 \mathrm{Org} / \mathrm{L}$ while the lead concentrations and the zooplankton densities ranged from $0.74 \mathrm{mg} / \mathrm{L}$ (September, 2007; wet season) to $4.63 \mathrm{mg} / \mathrm{L}$ (February and April, 2007; dry season) and 0.00 Org/L (July - September, 2006; November 2006 - April 2007 and October - November 2007) to 24.53
Org/L (December 2007; dry season) respectively. At site $D$ the mean lead concentration decreased from $2.84 \mathrm{mg} / \mathrm{L}$ at site C to $2.04 \mathrm{mg} / \mathrm{L}$. Similarly, the mean zooplankton density increased from $3.09 \mathrm{Org} / \mathrm{L}$ to $4.41 \mathrm{Org} / \mathrm{L}$ at this site. In addition, the zooplankton distribution across the months increased from 7 at site $C$ to 13 at site D (Table 2). However, the lead concentrations recorded at this site (site $D$ ) were generally higher than those at site $A$ and $B$ while the zooplankton densities were relatively lower.

Table 2 showed that two zooplankton maxima occurred, in which Cypris sp. (62.53 Org/L) and Brachionus $s p$. (64.48 Org/L) were the most dominant identified at the study sites. However, at site $B$ and $D$ only one maximum each was recorded in August 2007 (Table 1), which were 45.30 Org/L and $16.45 \mathrm{Org} / \mathrm{L}$ respectively. The dominant species at site B (Table 2) were Chaoborus $s p$. (22.12 Org/L) and also Brachionus sp. (53.07 Org/L). At site D the dominant species were Chaoborus sp. (14.55 Org/L) and Cypris sp. (36.15 Org/L). On the other hand, the highest density at site C (Table 2) was $24.53 \mathrm{Org} / \mathrm{L}$ and occurred in December 2007 during the dry season. At this site, the dominant species was Brachionus sp. (44.11 Org/L) followed by Stentor $s p$. with $4.77 \mathrm{Org} / \mathrm{L}$.

Comparison of lead concentrations at the different sites using analysis of variance (ANOVA) revealed significant difference $(P<0.01)$ and between the seasons $(P<0.05)$. However, no significant difference was found in the zooplankton availability with respect to sites and season $(P>0.05)$. The Pearson Correlation analysis for the relationship between lead concentration and zooplankton density at the sampling sites in the Challawa River showed a negative correlation $(r=-0.28734)$. Odum's Index (OI) computed to determine the pollution status of the river at the four sites showed that site $A$ was the cleanest while site $C$ was most polluted as the value of the index decrease with rise in pollution level $(A=$ $0.78 ; \mathrm{B}=0.67 ; \mathrm{C}=0.22$ and $\mathrm{D}=0.44$ ). 
Table 1: Variations in Lead Concentration and Total Zooplankton Density Along Challawa River (July 2006 - December 2007)

\begin{tabular}{|c|c|c|c|c|c|c|c|c|c|c|}
\hline \multirow[b]{2}{*}{ Month } & \multicolumn{3}{|c|}{ Lead $(\mathrm{mg} / \mathrm{L})$} & \multicolumn{5}{|c|}{$\begin{array}{l}\text { Zooplankton density (Org/L) } \\
\text { Site }\end{array}$} & \multicolumn{2}{|c|}{ WHO (1996) Limit (mg/L) } \\
\hline & $\mathbf{A}$ & B & $\mathbf{C}$ & D & $\mathbf{A}$ & $\mathbf{B}$ & $\mathbf{C}$ & D & Max.Acc. & Max. Allow. \\
\hline July 2006 & 1.02 & 1.48 & 2.78 & 1.67 & 18.80 & 9.58 & 0.00 & 3.51 & 0.05 & 0.10 \\
\hline August & 1.20 & 1.57 & 3.98 & 1.67 & 1.17 & 0.00 & 0.00 & 9.58 & 0.05 & 0.10 \\
\hline September & 1.39 & 1.39 & 2.41 & 1.20 & 2.78 & 1.39 & 0.00 & 6.34 & 0.05 & 0.10 \\
\hline October & 0.74 & 1.11 & 3.15 & 2.13 & 10.23 & 0.00 & 3.17 & 7.60 & 0.05 & 0.10 \\
\hline November & 1.30 & 1.57 & 3.52 & 2.50 & 9.53 & 0.00 & 0.00 & 13.02 & 0.05 & 0.10 \\
\hline December & 1.39 & 2.04 & 2.78 & 2.41 & 6.63 & 0.00 & 0.00 & 0.00 & 0.05 & 0.10 \\
\hline Jan. 2007 & 0.74 & 1.57 & 3.33 & 2.78 & 7.15 & 8.87 & 0.00 & 2.51 & 0.05 & 0.10 \\
\hline February & 1.48 & 1.57 & 4.63 & 3.33 & 1.21 & 2.81 & 0.00 & 0.00 & 0.05 & 0.10 \\
\hline March & 2.04 & 2.22 & 4.26 & 2.13 & 10.23 & 11.25 & 0.00 & 6.84 & 0.05 & 0.10 \\
\hline April & 1.94 & 2.31 & 4.63 & 3.24 & 33.88 & 13.92 & 0.00 & 0.00 & 0.05 & 0.10 \\
\hline May & 1.20 & 1.94 & 3.06 & 2.41 & 4.96 & 5.65 & 4.34 & 0.00 & 0.05 & 0.10 \\
\hline June & 1.39 & 1.94 & 3.61 & 2.69 & 2.28 & 5.71 & 1.39 & 2.76 & 0.05 & 0.10 \\
\hline July & 1.20 & 2.41 & 2.78 & 2.87 & 13.77 & 7.95 & 4.94 & 2.38 & 0.05 & 0.10 \\
\hline August & 1.85 & 1.20 & 1.85 & 1.20 & 35.91 & 45.30 & 11.93 & 16.45 & 0.05 & 0.10 \\
\hline September & 1.02 & 0.93 & 0.74 & 1.48 & 13.97 & 8.25 & 5.30 & 3.26 & 0.05 & 0.10 \\
\hline October & 0.74 & 1.02 & 1.39 & 0.65 & 9.33 & 3.18 & 0.00 & 2.30 & 0.05 & 0.10 \\
\hline November & 0.83 & 1.11 & 1.02 & 1.20 & 1.81 & 5.84 & 0.00 & 2.82 & 0.05 & 0.10 \\
\hline December & 1.02 & 1.02 & 1.20 & 1.11 & 0.00 & 19.62 & 24.53 & 0.00 & & \\
\hline Mean $(\mathrm{mg} / \mathrm{L})$ & 1.25 & 1.58 & 2.84 & 2.04 & 10.26 & 8.30 & 3.09 & 4.41 & 0.05 & 0.10 \\
\hline Std. Deviation & \pm 0.39 & \pm 0.46 & \pm 1.18 & \pm 0.77 & \pm 10.08 & \pm 10.38 & \pm 6.04 & \pm 4.61 & & \\
\hline
\end{tabular}

Key: $A=$ Near Garu bridge, $B=$ River intake, $C=$ Effluent inflow point, $D=$ Tamburawa bridge

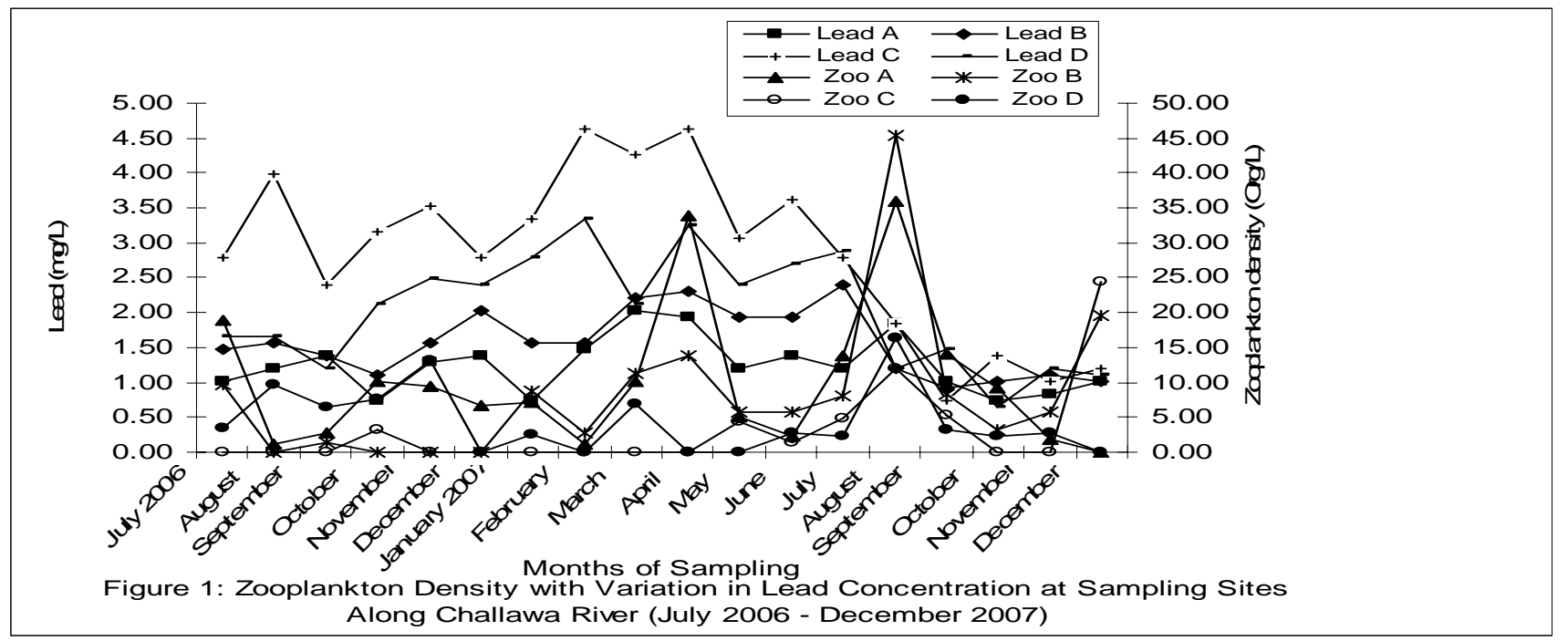


Table 2: Checklist for the Occurrence, Distribution and Relative Abundance of Zooplankton Species 8tthpling Sites Along Challawa River Basin (July 2006 - December 2007)

\begin{tabular}{|c|c|c|c|c|c|c|}
\hline \multirow[b]{2}{*}{ S/No.Taxon } & \multicolumn{4}{|c|}{ Site } & \multicolumn{2}{|r|}{ Frequency } \\
\hline & A & B & C & D ? & Total (Org/L) & (\%) \\
\hline Protozoa & & & & & & \\
\hline 1 Loxodes sp. & 1.24 & - & - & - & 1.24 & 25.00 \\
\hline 2 Urocentrum sp. & 3.75 & - & 3.17 & - & 6.92 & 50.00 \\
\hline 3 Vorticella sp. & 5.13 & - & - & 8.87 & 14.00 & 50.00 \\
\hline 4 Coleps sp. & 5.13 & - & - & - & 5.13 & 25.00 \\
\hline $\begin{array}{l}5 \text { Sarcodina sp. } \\
\text { Insecta }\end{array}$ & - & 1.39 & - & - & 1.39 & 25.00 \\
\hline 6 Chaoborus sp. & 1.28 & 22.12 & - & 14.55 & 37.95 & 75.00 \\
\hline 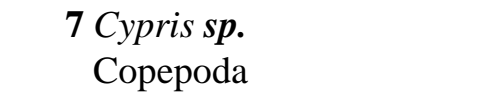 & 63.53 & 21.76 & 3.55 & 36.15 & 124.99 & 100.00 \\
\hline 8 Macrocyclops ater & 8.90 & 12.44 & - & 3.84 & 25.18 & 75.00 \\
\hline 9 Senecella calanoidea & 1.26 & 1.39 & - & - & 2.65 & 50.00 \\
\hline 10 Cyclops sp. & 5.13 & 5.30 & - & - & 10.43 & 50.00 \\
\hline 11 Limnocalanus macrurus & - & 2.83 & - & - & 2.83 & 25.00 \\
\hline $\begin{array}{l}12 \text { Naplius I of copepoda } \\
\text { Cladocera }\end{array}$ & 1.24 & 1.41 & - & - & 2.65 & 50.00 \\
\hline $\begin{array}{l}13 \text { Daphnia pulex } \\
\text { Rotifera }\end{array}$ & 6.94 & 11.30 & - & 3.26 & 21.50 & 75.00 \\
\hline 14 Brachionus sp. & 64.48 & 53.07 & 44.11 & 7.70 & 169.36 & 100.00 \\
\hline 15 Asphlanchna brightwelli & 1.24 & - & - & - & 1.24 & 25.00 \\
\hline 16 Stentor sp. & 15.39 & 10.60 & 4.77 & 2.47 & 33.23 & 100.00 \\
\hline 17 Rotararia sp. & - & 5.71 & - & - & 5.71 & 25.00 \\
\hline 18 Philodina sp. & - & - & - & 2.53 & 2.53 & 25.00 \\
\hline Total (Org/L) (\%) & $\begin{array}{l}184.64 \\
(39.38)\end{array}$ & $\begin{array}{l}149.32 \\
(31.84)\end{array}$ & $\begin{array}{r}55.60 \\
(11.86)\end{array}$ & $\begin{array}{r}79.37 \\
(16.92)\end{array}$ & $\begin{array}{r}468.93 \\
(100.00)\end{array}$ & \\
\hline Frequency/ & 14 & 12 & 4 & 8 & & 18 \\
\hline Site (\%) & (77.78) & (66.67) & (22.22) & (44.44) & & $(100.00)$ \\
\hline
\end{tabular}

Key: - means the species was not encountered

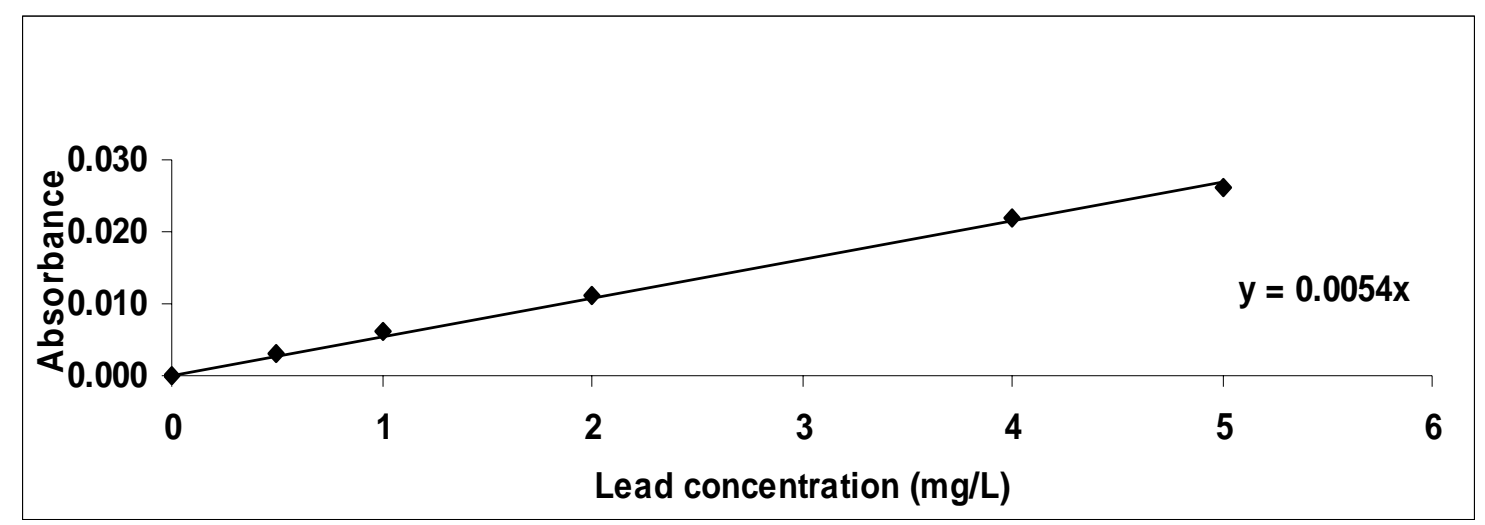

Figure 2: Calibration Graph for the Determination of Lead from Water Samples Collected from Challawa River (July 2006-December 2007) 


\section{DISCUSSION}

All the mean lead concentrations recorded from the sampling sites were far above the maximum acceptable and maximum allowable concentrations in drinking water of $0.05 \mathrm{mg} / \mathrm{L}$ and $0.10 \mathrm{mg} / \mathrm{L}$ respectively (WHO, 1996). This observation implies that inorganic loads into the river from domestic, agricultural and industrial sources along the river have high lead content coupled with the nature of its bed rock (Olofin, 1980; and Elliot, 1996). The above results indicated that elevated lead levels in drinking water from this river can occur and possibly cause lead poisoning (NSC, 2005). Indeed, as Redmond (2008) has reported that high lead concentration in the human body can reduce intelligence, delay motor development, impaired memory, cause hearing problems and troubles in balance, it follows that there is a great fear that lead poisoning can occur as a result of its bioaccumulation over time if raw water from the river is consumed over a long period of time.

The observation of double maxima in the total zooplankton density (Table 1 ) recorded from site A corroborate the reports of Ovie (1997), and Okogwo and Ugwumba (2006) that plankton maxima may occur at any time of the year in the tropics, depending on the prevailing set of physical, chemical and biological conditions of the ecosystem.

. Generally, the unstable nature of the study sites seemed to be responsible for the fluctuations and sometimes complete absence of organisms during the study period. Moreover, even under favourable environmental conditions, zooplanktons such as Cladocera may be monocyclic or dicyclic, with one or two population maxima during the year (Pennak, 1978). Cladocerans such as Daphnia pulex are also found to be rare in rapid streams and grossly polluted waters (Pennak, 1978), thus, absent at site C. Additionally, some species, particularly rotifers, have been found to unaccountably disappear for one or more years although they are cosmopolitan in distribution (Pennak, 1978), thus least diversity was recorded at site C (4 species only). Similarly, copepods are reported to be either absent or present in small numbers in streams and therefore rivers by extension (Pennak, 1978) and therefore none was recovered from site $C$ and $D$, and only four species

\section{REFERENCES}

Abubakar, M. M. (1998): Effects of Pollution on Phytoplankton Distribution in Salanta and Challawa Rivers, Kano, Nigeria. M.Sc. Thesis, Department of Biological Sciences, Bayero University, Kano. P. 4-26.

Africa (2007):. New Treatment Plant Leaves Kano Short of Water. By IRIN 1/1/08, Jan 2, 2008 - 11:36:50AM. http://www.ocnus.net/

Aminu, M. (1988): Analysis of Sharada Industrial Effluents. B. Sc. Thesis (Unpublished), Department of Chemistry, Bayero University, Kano, Nigeria. P. 1-30.

Ayodele, H. A. and Adeniyi, I. F. (2006): The Zooplankton Fauna of Six Impoundments on and one naplius I stage were recovered from site A and B. Consequently, the highest total density recorded among all the copepods during this study was $12.44 \mathrm{Org} / \mathrm{L}$ at site B (Table 2). In the same line, the zooplanktons identified were very low in population due to the above reasons coupled with their inability to maintain footing and therefore develop a stable community in lotic environment, which is fundamental for reproduction success as earlier reported by Dejen et al., (2004) and Ogbeibu and Edutie (2005).

The re-emergence of 8 zooplankton species at site $\mathrm{D}$ (Table 2) down stream, seemed to indicate the ability of the river to undergo self purification (Gardner and Brooks, 1980). The progressive decrease in the zooplankton density and diversity from site $A$ to $C$ could be attributed to the degrading quality of the river down stream, which subsequently contributes to water pollution with a lot of negative impact on some important aquatic fauna and flora (Akingide, 2000). The above effects ranged from decreasing population of some individuals to extermination of others, where adaptation to the unfavourable changes could not be met by the affected species as observed particularly at site $C$ and D during this study. Thus, least recovery from site $C$ was probably due to its highest level of pollution (Biswas and Arar, 1998). Also, the recovery of Chaoborus sp. (a macro-invertebrate) at site A, B and $\mathrm{D}$ (Table 2) is an indication of high turbulence rate of the river (Howick and Wilhm, 1984) since it is essentially a benthic organism.

\section{CONCLUSION}

It can be concluded that the low diversity and density in the zooplankton identified from Challawa River are clear indication of unstable aquatic community with negative effect on the aquatic fauna. In view of the above, appropriate authorities need to take measures with the view to reducing the pollution menace in the river particularly due to the industrial effluents. More over, consumption of raw Challawa River water can be of great health risk due to its high lead content and that necessary attention need to be paid to the purification processes in the waterworks so as to ensure a healthy community.

the River Osun, Southern Nigeria. The Zoologist 1(4): 49-67.

Akinjide, O. (2000): Environmental Problems of the Niger-Delta. Friedrich Ebert Foundation, Lagos, Nigeria. 280pp.

Biswas, A. K. and Arar, A. (1998): Treatment and Reuse of Wastewater. Butterworths, London.

Dejen, E., Vijverberg, J., Nagelkerke, L. A. J. and Sibbing, F. A. (2004): Temporal and Spatial Distribution of Microcustacean Zooplankton in Relation to Turbidity and Other Environmental Factors in Large Tropical Lake (L Tana, Ethiopia). Hydrobiologia. 513:39-49.

Edmondson, W. T. (1959): Freshwater Biology (ed.). John Wiley and Sons, Inc., USA. 1248pp. 
Elliot, O. O. (1996): Overview of Fisheries Sub-sector in Nigeria. Paper presented at National Workshop on Prevention of Obnoxious Fishing Practices and Promotion of Responsible Inland Fishing Practices. UNDPNIGERIA, 4th Country Programme. P.22 (In Akinjide, O. ed., (2000): Environmental Problems of the Niger-Delta. Friedrich Ebert Foundation, Lagos, Nigeria. P.80.

Gardner, B. D. and Brooks, P. M. (1980): Effect of Cattle Dip Containing Taxaphene on Fauna of the South African River. Journal of the Limnological Society of Southern Africa. 6 (2): $113-118$.

Geraldes, A. M. and Boavida, M. (2007): Zooplankton assemblages in two reservoirs: one subjected to accentuated water level fluctuations, the other with more stable water levels. Aquatic Ecology, 41(2):273284.

Gregg, A. I. (1989): Heavy Metals Determination in Water Samples Using Concentrated Nitric Acid. J. Environ. Poll. 4:23-25.

Hadiza, B. (1998): Responses of Tropically Mixed Phytoplankton and Zooplankton Populations to Industrial Effluents in Kano. M. Sc. Thesis, Department of Biological Sciences, Bayero University, Kano (Unpublished). P. 8-23.

Howick, G. L. and Wilhm, J. (1984): Zooplankton and Benthic Macroinvertebrates in Lake Carl Blackwell. Proceedings of the Oklahoma Academy of Science. 64:63-65. http://www.digital.library.oklastate.edu/oas

Jeje, C. Y. and Fernando, C. H. (1986): A Practical Guide to the Identification of Nigerian Zooplankton (cladocera, copepoda and rotifera). Kainji Lake Research Institute, Nigeria. 142pp.

Kawo, A. H. and Ajagbe, J. M. (2001): Urban Growth and Water Born Diseases in Kano, Nigeria. African Journal of Material and Natural Sciences 1(3): 45-51.

Kawo, A. H. and Deeni, Y. Y. (2002): Microbial Ecological Studies on Getsi River- An Industrial Tributary of Jakara River, Kano, Nigeria. African Journal of Material and Natural Sciences, 2(2): 93- 97.

Maiti, S. K. (2004): Handbook of Methods in Environmental Studies. Water and Wastewater Analysis. Vol. 1.ABD Publishers, Jaipur, India. Pp. 242-246.

Meyer, J. R. (1998): Species Diversity. http://www.cals.ncsu.edu/course/ent591k/gc extend.html

Mission Creek (2004): Distinguished Project of the Year Award. - Water Facilities. Awarded by American Public Association, North California Chapter. Guide to Identification of Freshwater Organisms.

http://www.msnucleus.org/watersheds/missi on/Holoplankton.html...and http://www.msnucleus.org/watersheds/missi on/Meroplankton.html

Nlewadim, A. A. and Adeyemo, A. A. (1998): Effect of Inorganic Fertilization on Zooplankton Production in Brackish Water (ed.). Selected Papers from $9^{\text {th }} / 10^{\text {th }}$ Annual Conference of the Nigerian Association for Aquatic Sciences. Theme: Sustainable Utilization of Aquatic/wetland Resources, held at University of Agriculture, Abeokuta, Ogun State, Nigeria, $30^{\text {th }}$ November $-2^{\text {nd }}$ December, 1995. P.75 - 82.

NSC (National Safety Council, 2005): Lead in water. http://www.leadtesting.org/.

Ogbeibu, A. E. and Edutie, L. O. (2005): Effects of Brewery Effluent on the Water Quality and Rotifers of the Ikpoba River, Southern Nigeria. 1(1): Art 1. Ecoserve Publishers. http://www.ecoservepublishers.org

Okogwu, O. I. and Ugwumba, O. A. (2006): The Zooplankton and Environmental Characteristics of Ologe Lagoon, South West Nigeria. The Zoologist 1(4): 86-92.

Olofin, E. A. (1980): Some Aspects of Tiga Dam on the Environment Downstream in the Kano River Basin. Ahmadu Bello University, Zaria, Nigeria. Ph.D Thesis.

Omoregie, E., Ufodike, E. B. C. and Onwuliri, C. O. E. (1995): Effects of Petroleum Effluents on Carbohydrate Reserves of the Nile Tilapia(Oreochromis nilotica (L)).West African Journal of Biological Sciences $3(1 \&$ 2):Pp.70-76.

Ovie, S. I. (1997): The Ecology and Culture of the Zooplankton of Jebba Lake, Nigeria. Ph.D. Thesis, University of Benin, Benin City, Nigeria. 240pp.

Patterson, D. J. and Hedley, S. (1992): Free-living Freshwater Protozoa: A Colour Guide. Wolf, England. 223pp.

Pennak, R. W. (1978): Freshwater Invertebrates of the United States (ed.). John Wiley and Sons Inc. USA. 803pp.

SAS (1985): Statistical Analysis System Institute Inc., SAS/STAT User's Guide Version. $5^{\text {th }}$ edn., Vol. 1, Cary, NC.

Redmond, W. A. (2008): Lead."Microsoft $₫$ Encarta $($ ) 2007 [DVD]. Microsoft Corporation, 2007.

Sutherland W. J. (1997): Ecological Census Techniques. A Handbook. Cambridge University Press, Cambridge. 336pp.

WHO (1996): Guidelines for Drinking Water and Wastewater Quality Vol. 2: Health Criteria and Other Supporting Information. $2^{\text {nd }}$ ed., Geneva. $152-279$.

World Health Organization (WHO, 2003): Recommended Revised Microbiological Guidelines for Treated Wastewater Used in Agriculture. Environmental Letters 1(3): 2639. 